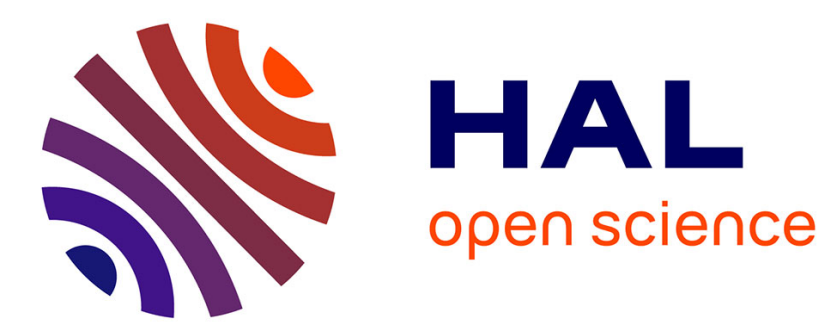

\title{
Streaming potential in volcanic rocks from Mount Pelée
}

\author{
Laurence Jouniaux, Marie-Lise Bernard, Maria Zamora, Jean-Pierre Pozzi
}

\section{To cite this version:}

Laurence Jouniaux, Marie-Lise Bernard, Maria Zamora, Jean-Pierre Pozzi. Streaming potential in volcanic rocks from Mount Pelée. Journal of Geophysical Research, 2000, 105 (B4), pp.8391-8401. 10.1029/1999JB900435 . hal-01977548

\section{HAL Id: hal-01977548 \\ https://hal.univ-antilles.fr/hal-01977548}

Submitted on 26 May 2020

HAL is a multi-disciplinary open access archive for the deposit and dissemination of scientific research documents, whether they are published or not. The documents may come from teaching and research institutions in France or abroad, or from public or private research centers.
L'archive ouverte pluridisciplinaire HAL, est destinée au dépôt et à la diffusion de documents scientifiques de niveau recherche, publiés ou non, émanant des établissements d'enseignement et de recherche français ou étrangers, des laboratoires publics ou privés. 


\title{
Streaming potential in volcanic rocks from Mount Pelée
}

\author{
Laurence Jouniaux \\ Ecole Normale Supérieure de Paris, Unité Mixte de Recherche 8538, CNRS, Paris \\ Marie Lise Bernard and Maria Zamora \\ Institut de Physique du Globe de Paris, ESA 7046, CNRS, Université Denis Diderot, Paris \\ Jean Pierre Pozzi \\ Ecole Normale Supérieure de Paris, Unité Mixte de Recherche 8538, CNRS, Paris
}

\begin{abstract}
Streaming potential and electric conductivity have been measured in a laboratory on 11 consolidated samples coming from five deposits of the different evolutionary stages of Mount Pelée volcano. The streaming potential coupling coefficient ranges from -35 to $-4905 \mathrm{mV} \mathrm{MPa}{ }^{-1}$ and increases with increasing permeability. This increase is mainly due to the dependency of rock effective conductivity with permeability. The permeability of the samples varies from $0.146 \times 10^{-12}$ to $34 \times 10^{-12} \mathrm{~m}^{2}$. The zeta potential, at $\mathrm{pH}=7$ and water conductivity of $2.1 \times 10^{-4} \mathrm{~S} \mathrm{~m}^{-1}$, is relatively small for the majority of the samples. It ranges from -4 to $-19 \mathrm{mV}$. According to water conductivity analysis on Mount Pelée, streaming potential coupling coefficients of -25 to $-406 \mathrm{mV} \mathrm{MPa}^{-1}$ can be expected for this volcano.
\end{abstract}

\section{Introduction}

Monitoring of electric and magnetic anomalies has been proposed as a means of predicting earthquakes [Mizutani et al., 1976; Fenoglio et al., 1995; Trique et al., 1999] or volcanic eruptions [Zlotnıckı et al., 1998]. Magnetic observations made on La Soufrière volcano (Guadeloupe, France) have shown magnetic variations that could be induced by electric fields related to deepwater circulation (approximately at a depth of $5 \mathrm{~km}$ ) [Pozzi et al., 1979]. Water circulation is also thought to be the main agent of the strong magnetic signals observed on Piton de La Fournaise volcano (Réunion Island, France) [Zlotnıcki and Le Mouël, 1990].

Self-potential (SP) anomalies can be produced by a streaming potential, as a consequence of fluid pressure gradients (an electrokinetic phenomenon); by a thermoelectric potential, as a consequence of a temperature gradient; by a chemical potential, as a consequence of a chemical gradient; or by these effects possibly acting together. Indeed, SP anomalies have been shown to be related to hydrothermal activity (two-phase water and steam flow) in geothermal areas and on active volcanoes [Zohdy et al., 1973; Anderson and Johnson, 1976; Corwin and Hoover, 1979; Michel and Zlotnıckı, 1998].

Copyright 2000 by the American Geophysical Union.

Paper number 1999JB900435. 0148-0227/00/1999JB900435\$09.00
Electrokinetic phenomena were proposed as a possible mechanism for generating SP anomalies observed in geothermal areas [Corwin and Hoover, 1979; Revul and Pezard, 1998]. Some significant SP variations have been observed associated with volcanic activity and can precede eruptive episodes [Aubert and Kueffer, 1984; Malengreau et al., 1994]. SP anomalies are commonly thought to be induced by electrokinetic phenomena because, thermoelectric and chemical coefficients are smaller than the electrokinetic coefficient [Nourbehecht, 1963; Sull, 1983; Futterman, 1979; Perrier et al., 1998, 1999]. SP surveys performed on Etna, Lamonga, and Merapi volcanoes have shown that the amplitude of the anomalies was related to the vapor flow, and the main source of these SP anomalies was thought to be electrokinetic [Aubert and Dana, 1994]. In some areas there is a good spatial correlation on active volcanoes between rising two-phase convective cells and positive SP anomalies [Aubert et al., 1984; Aubert and Baubron, 1988]. SP measurements on La Fournaise volcano (Réunion Island, France) have shown a huge positive anomaly of amplitude more than +1850 $\mathrm{mV}$ on the cone. This anomaly suggests that hydrothermal ascendant circulations within the cone are induced by a magmatic complex source at least at 2 $\mathrm{km}$ depth beneath the summit [Zlotnick et al., 1994]. Recent SP measurements on Unzen volcano (Kyushu Island, Japan) showed a positive anomaly as large as $+1000 \mathrm{mV}$ per $500 \mathrm{~m}$ in the vicinity of the newly extruded lava dome. The most reasonable mechanism 
for this anomaly is thought to be streaming potentials associated with subsurface hydrothermal convection [Hashımoto and Tanaka, 1995]. A sharp increase of +500 to $+600 \mathrm{mV}$ in SP was detected 3 months preceding the first extrusion of lava and was considered to be a result of the growth of the hydrothermal system. Moreover, Fujinawa et al. [1992] measured an anomalous vertical electric field of about $+30 \mathrm{mV}$ a few days prior to, and a month after, a minor volcanic eruption of Mount Mihara. These anomalous variations were thought to be generated by electrokinetic phenomena induced by variations of hydrothermal circulation around the crater, or by variations of crack density, due to volcanic activity.

Modeling of all these observations needs a good understanding of electrokinetic phenomena in volcanic rocks, specially the effect of the most influential parameters on streaming potential. These effects can be quantified in the laboratory. Few laboratory data of geophysical interest on streaming potential are available [ $A h$ mad, 1964; Somasundaran and Kulkarni, 1973; Ishıdo and Mizutanı, 1981; Jounıaux et al., 1994; Pozzı and Jouniaux, 1994; Jouniaux and Pozzi, 1995a, b, 1997; Lorne et al., 1999a, b], and few can be applied directly to volcanic environments [Massenet, 1983; Massenet and Van Ngoc, 1985; Antraygues and Aubert, 1993].

We present in this paper laboratory measurements of streaming potential and electric conductivity on 11 volcanic samples representative of the main lithologies and textures of the Mount Pelée volcano.

\section{Electrokinetic Phenomena}

Electrokinetic phenomena are induced by the relative motion between the fluid and the rock. Minerals forming the rock develop an electric double layer when in contact with an electrolyte, usually resulting from a negatively charged mineral surface. An electric field is created perpendicular to the surface of the mineral which attracts counterions (usually cations) and repulses anions in the vicinity of the pore-matrix interface. The electric double layer is made up of the Stern layer, where cations are adsorbed on the surface, and the Gouy diffuse layer, where the number of counterions exceeds the number of anions (for a detailed description, see Adamson [1976] and Hunter [1981]). The streaming potential is due to the motion of the diffuse layer induced by a fluid pressure difference along the interface. The zeta potential is defined at the slipping plane or shear plane (i.e., the potential within the double layer at the zero-velocity surface). In a porous medium the electric current density and the fluid flux are coupled [Overbeek, 1952; Nourbehecht, 1963], so that the streaming potentials are generated by fluids moving through porous media.

The parameter that quantifies this coupling is the streaming potential coupling coefficient or, simply, the coupling coefficient, defined by

$$
C_{S}=\frac{\Delta V}{\Delta P}=\frac{\epsilon \zeta}{\eta \sigma_{\mathrm{eff}}}
$$

where $\Delta V$ is the generated electrical potential, $\Delta P$ is the applied pore pressure difference, $\epsilon$ is the dielectric constant of the pore fluid $\left(\epsilon=7 \times 10^{-10} \mathrm{~F} \mathrm{~m}^{-1}\right), \zeta$ is the zeta potential, $\eta$ is the dynamic viscosity of the pore fluid $\left(\eta=10^{-3} \mathrm{~Pa} \mathrm{~s}\right)$, and $\sigma_{\text {eff }}$ is the effective conductivity defined by

$$
\sigma_{\mathrm{eff}}=F \sigma_{r},
$$

where $F$ is the formation factor and $\sigma_{r}$ is the rock electrical conductivity at the fluid conductivity used for electrokinetic measurements.

If surface conductivity is negligible, $\sigma_{\text {eff }}=\sigma_{f}$, and we have

$$
C_{S}=\frac{\epsilon \zeta}{\eta \sigma_{f}},
$$

which is the Helmholtz-Smoluchowski equation [Ishıdo and Mizutanı, 1981]. When we want to be free from the effect of the effective conductivity, another parameter, $C^{\prime}$, independent on this conductivity is defined,

$$
C^{\prime}=\frac{\Delta V}{\Delta P} \sigma_{\mathrm{eff}}=\frac{\epsilon \zeta}{\eta},
$$

where $C^{\prime}$ is called the electrokinetic coefficient.

For a complete development of the equations governing the coupled electro-magnetics and flow of the porous media, see Pride [1994] and Revrl et al. [1999a, b], for modeling of electrokinetics in porous rocks see Coelho et al. [1996] and Bernabé [1998], and for further details on surface conductivity, see Reval and Glover [1997, 1998].

\section{Experimental Procedures}

Streaming potential and electric conductivity measurements have been performed on 11 consolidated samples coming from five deposits of the different evolutionary stages of Mount Pelée. This explosive volcano, located in the north end of Martinique Island in the Lesser Antilles (France), is mainly composed of andesitic pyroclastic materials. The sampling represented different lithologies and textures typically found on this volcano (dense or porous block, pumice, and scoria). Mineralogical and chemical compositions are relatively constant [Westercamp, 1976; Fichaut et al., 1989; Vincent et al., 1989]. Plagioclase, orthopyroxene, clinopyroxene, and a few magnetite are the main phenocrystals (with the following mean proportion: $33 \%$ plagioclase, $8 \%$ pyroxene, and $2.8 \%$ magnetite). The groundmass of the samples ranges from 52 to $63 \%$. It is composed of variable percentages of glass and microcrystals. The proportion of the different mineral phases and the groundmass varies from one eruption to another. A short description of the samples is presented in Table 1.

\subsection{Sample Preparation}

Two samples were cored on each block of rock: (1) cylinder, $23 \mathrm{~mm}$ in diameter and $25-50 \mathrm{~mm}$ length, for porosity, permeability, and electrical conductivity measurements, and (2) cylinder, $2.5 \mathrm{~cm}$ in diameter and 48 $\mathrm{mm}$ long, for streaming potential measurements. The 
Table 1. Description of the Samples

\begin{tabular}{|c|c|c|c|c|}
\hline Stage & Eruption & Sample & Deposit & Description \\
\hline Paleo-Pelée & & $\begin{array}{l}\text { MA701 (1) } \\
\text { MA701 (3) }\end{array}$ & $\begin{array}{l}\text { volcanic breccias } \\
\text { volcanic breccias }\end{array}$ & vesicular andesite blocks \\
\hline Neo-Pelée & $\begin{array}{l}\text { Saint Vincent } \\
\text { Saint Vincent } \\
\text { Saint Vincent }\end{array}$ & $\begin{array}{l}M F 201(1) \\
M F 201(2) \\
M F 201\end{array}$ & $\begin{array}{l}\text { scoria flows } \\
\text { scoria flows } \\
\text { scoria flows }\end{array}$ & $\begin{array}{l}\text { andesite scoriaceous blocks } \\
\text { andesite scoriaceous blocks } \\
\text { andesite scoriaceous blocks }\end{array}$ \\
\hline Modern stage & $\begin{array}{l}\mathrm{P} 1 \\
\mathrm{P} 1 \\
1902 \\
1902 \\
1929 \\
1929\end{array}$ & $\begin{array}{l}\mathrm{F} 3 \\
\mathrm{M} \\
\mathrm{K} \\
\mathrm{J} \\
\mathrm{R} \\
\mathrm{Q}\end{array}$ & $\begin{array}{l}\text { Pelean nuees ardentes } \\
\text { Plinian fallout } \\
\text { Pelean nuees ardentes } \\
\text { Plinian fallout } \\
\text { Block-and-ash flows } \\
\text { Block-and-ash flows }\end{array}$ & $\begin{array}{l}\text { lightly vesicular andesite block } \\
\text { andesitic pumice } \\
\text { vesicular grey andesite } \\
\text { white andesitic pumice } \\
\text { vesiculated andesite } \\
\text { highly vesicular andesite }\end{array}$ \\
\hline
\end{tabular}

end faces of the samples were ground flat and parallel to within $0.025 \mathrm{~mm}$.

\subsection{Porosity and Air Permeability Measurements}

The matrix mass density $\rho_{m}$ was measured with a pycnometer on $2-3 \mathrm{~g}$ of rock reduced on fine powder (10 $\mu \mathrm{m})$. The porosity was measured with the triple weighing method: the sample was first oven dried at $70^{\circ} \mathrm{C}$ for at least 48 hours, slowly cooled to room temperature, and then saturated with degassed water under vacuum. The sample is weighed before saturation, and after saturation and immersed (saturated sample) within the water. These three measurements and the matrix mass density allow us to calculate the connected, $\phi_{C}$, and trapped porosity, $\phi_{T}$. The trapped porosity is the part of porosity not accessible under vacuum. The experimental error on porosity was less than $1 \%$.

The air permeability $k$ was measured, at atmospheric pressure, with a falling head permeameter (see Bourbzé and Zınszner [1985] for a description of the apparatus). The accuracy is within $1 \%$ for permeabilities greater than $10^{-16} \mathrm{~m}^{2}$. The Klinkenberg effect is only significant in the three less permeable samples, and it is always less than $6 \%$. Measurements were repeated several times for reliability.

\subsection{Electric Conductivity Measurements}

In order to determine the electrical formation factor $F$, the electrical conductivity of the rock was measured, at room conditions, when the samples were saturated successively with a distilled water and with at least seven aqueous $\mathrm{NaCl}$ solutions with conductivities increasing from $6 \times 10^{-4}$ to $17 \mathrm{~S} \mathrm{~m}^{-1}$. The electrical conductivity measurements were performed with twopole electrodes, a technique consisting in the measure of the electrical impedance of the samples, at different frequencies (varying from 100 to $100 \mathrm{kHz}$ ), by placing the sample between two stainless steel electrodes, connected to an impedance meter (HP4263A). Filter paper disks soaked with the saturating solution were put between the electrodes and each end of the sample to reduce contact resistance and to prevent polarization ef- fects. A clamping system held the sample between the electrodes with the same constant force for each sample. The electrolyte conductivity was measured with a conductivity cell (Knick 702).

The following experimental procedure was used:

1. The sample was first dried for at least 48 hours at $70^{\circ} \mathrm{C}$, cooled to room temperature, and placed in a container under dynamic vacuum for 4 hours. The container was then filled with distilled and degassed water and left under vacuum for 48 hours.

2. Samples were inserted quickly inside an insulating adhesive jacket to limit water evaporation during measurements and to prevent electrolyte conduction on the external surface sample. The electrical impedance of the sample and the conductivity of the solution were then measured.

3. After these measurements the samples were dried and again saturated with a degassed $\mathrm{NaCl}$ solution of $2 \times 10^{-4} \mathrm{~mol} \mathrm{~L}^{-1}$, and the electrical measurements were performed. The saturation conditions and the procedure of measurements were those described in the previous paragraph.

4. This procedure was reiterated for the other six $\mathrm{NaCl}$ solutions. Between two measurements, with two different saline solutions, the samples were carefully cleaned by saturating them several times with distilled water. The relative experimental error was less than $1 \%$ and $0.5 \%$ for rock conductivity and fluid conductivity measurements, respectively.

The formation factor was determined by nonlinear inversion of the experimental data, using the Revil and Glover [1998] model:

$$
\begin{gathered}
\sigma_{r}=\frac{\sigma_{f}}{F} H(\xi) \\
H(\xi)=1-t_{(+)}^{f}+F \xi+\frac{1}{2}\left(t_{(+)}^{f}-\xi\right) \\
\times\left(1-\frac{\xi}{t_{(+)}^{f}}+\sqrt{\left(1-\frac{\xi}{t_{(+)}^{f}}\right)^{2}+\frac{4 F \xi}{t_{(+)}^{f}}}\right),
\end{gathered}
$$

where $t_{(+)}^{f}$ is the Hittorf number of the cations (fraction 
of the electrical current carried in the free electrolyte by the cations), F and $\Phi$ are the formation factor and the porosity, respectively, and the dimensionless parameter $\xi$ is defined by Kan and Sen [1987]

$$
\xi=\frac{\sigma_{S}}{\sigma_{f}}=\frac{2}{3}\left(\frac{\Phi}{1-\Phi}\right) \frac{\beta_{S} Q_{V}}{\sigma_{f}},
$$

where $\sigma_{S}$ is the surface conductivity, $\beta_{S}$ is the surface mobility of the counterions, and $Q_{V}$ is the excess surface charges per unit of pore volume. The inversion procedure is described by Bernard [1999]. Only the data unaffected by the polarization effects were used for the inversion. For most of the samples the frequency which allows the electric impedance to be a pure resistance is $10 \mathrm{kHz}$.

\subsection{Streaming Potential Measurements}

The samples were first saturated with deionized water under vacuum for 8 hours. Electrical potential was measured while water was made to flow through the sample using the apparatus described in Figure 1. A silicone jacket was put around the sample to ensure the separation of the water and the confining fluid. A confining pressure (maximum $300 \mathrm{kPa}$ ) could be applied using the compressed air. The axial load was applied using lead weights of $50 \mathrm{~kg}$, so that the axial stress on the sample was of the order of $1 \mathrm{MPa}$. This system allows a water to circulate through the sample with a maximum pressure gradient of $300 \mathrm{kPa}$. The water pressure, measured with a manometer, was controlled by applying compressed air pressure to a water reservoir at one end of the sample while the other end was maintained at atmospheric pressure. The tubing circuit was not closed, so that there was no possible electric current leakage through the water within the tubing. Most of the tubing is plastic, and the few metallic parts of the apparatus were grounded. The electric potential was measured by two silver-chloride electrodes of length $40 \mathrm{~mm}$, which were made by electrolysis of a silver rod in salt water of concentration $10^{-1} \mathrm{~mol} \mathrm{~L}^{-1}$. The electrodes were put in the water circuit near the ends of the sample but not within the water circulation to avoid the electrical noise due to water movement near the electrodes. The two electrodes are connected by two coaxial cables to a high-input impedance (above $10^{10} \Omega$ ) volt meter. The resistance of the sample was usually several hundred $\mathrm{k} \Omega$ to a maximum of $1 \mathrm{M} \Omega$, which is low compared to the input impedance of the volt meter, therefore allowing accurate measurements of the potentials.

Streaming potential measurements were performed once equilibrium in water $\mathrm{pH}$ and water conductivity was attained: first, deionized water was made to flow through the sample, then collected, transferred to the upstream reservoir, and flowed through the sample again. The same procedure was repeated until the conductivity and $\mathrm{pH}$ of the water after flowing through the sample were constant. The volume of water flowing through the sample during this procedure ranged between 5 and $1000 \mathrm{~cm}^{3}$, depending on the sample per-
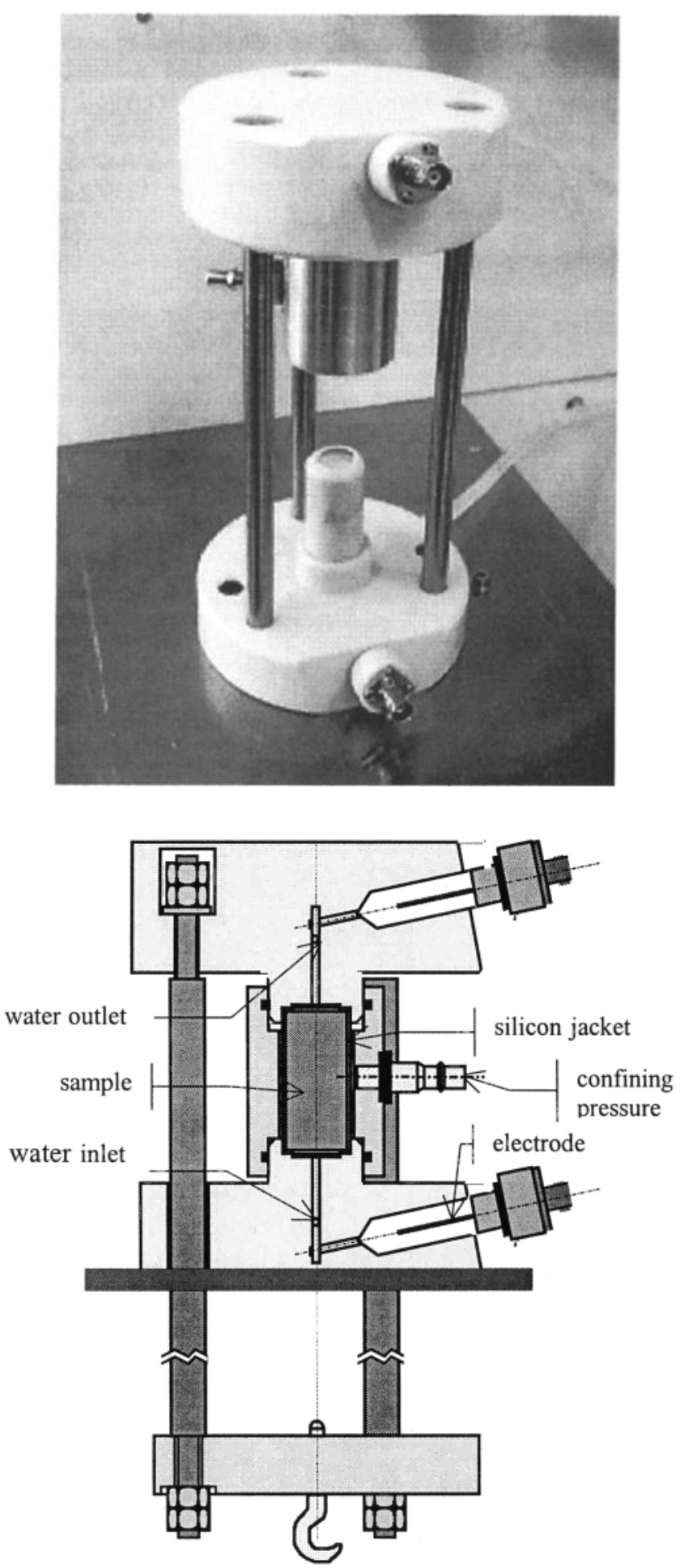

Figure 1. Apparatus used for electrokinetic measurements.

meability (volume of the sample is $23.6 \mathrm{~cm}^{3}$ ). Once the water conductivity and $\mathrm{pH}$ were constant, the streaming potential was measured for various water pressure gradients $(10-180 \mathrm{kPa})$. The water expelled from the sample was also analyzed. Samples with permeability below $10^{-13} \mathrm{~m}^{2}$ were not tested, because the water flow produced with the applied pore pressures would have 
Table 2. Connected and Trapped Porosities, Permeability, and Electrical Formation Factor for Each Sample

\begin{tabular}{lrrrrr}
\hline Sample & $\phi_{C}$ & \multicolumn{1}{c}{$\phi_{T}$} & \multicolumn{1}{c}{$k$} & $F$ & $\sigma_{T}$ \\
\hline R & 32.8 & 3.1 & 10342 & 9 & 0.19 \\
Q & 38.0 & 3.8 & 34325 & 9 & 0.19 \\
K & 25.1 & 2.3 & 1604 & 17 & 0.22 \\
MF201 (1) & 36.3 & 2.6 & 1564 & 16 & 0.85 \\
MA701 (3) & 28.9 & 2.3 & 5124 & 19 & 0.41 \\
J & 57.5 & 6.8 & 393 & 31 & 0.68 \\
F3 & 14.6 & 1.7 & 207 & 65 & 0.15 \\
M & 57.4 & 10.0 & 146 & 40 & 0.76 \\
MF201 (3) & 35.2 & 2.9 & 5765 & 9 & 1.34 \\
MA701 (1) & 24.0 & 0.1 & 257 & 18 & 1.01 \\
MF201 (2) & 28.0 & 1.6 & 1043 & 25 & 0.43 \\
\end{tabular}

Note that $\phi_{C}$ indicates connected porosity, in percent, $\phi_{T}$ indicates trapped porosity, in percent, $k$ indicates permeability, in $10^{-15} \mathrm{~m}^{2}, F$ indicates formation factor, and $\sigma_{T}$ indicates the rock conductivity, in $\mathrm{mS} \mathrm{m}^{-1}$.

been too small to induce a measurable electrokinetic effect. For lower permeabilities an apparatus similar to the one used with the pulse method to measure low permeabilities is needed [Jouniaux et al., 1994].

\section{Results and Discussion}

\subsection{Porosity, Permeability, and Electrical Conductivity}

Connected porosity in the samples ranges from 14.6 to $57.5 \%$, and trapped porosity can reach $10 \%$ (Table 2 ). Permeability ranges from $0.146 \times 10^{-12}$ to $34 \times 10^{-12} \mathrm{~m}^{2}$. The most permeable samples have permeabilities higher than $10^{-11} \mathrm{~m}^{2}$, which corresponds to very permeable materials such as sand.

Figure 2 shows an example of the dependence of the rock electrical conductivity versus the saturating fluid conductivity, with the fit obtained using the Revrl and Glover [1998] model. Formation factor values are reported in Table 2 and range from 9 to 65 . We note a tendency of $\mathrm{F}$ to decrease with increasing permeability as shown in Figure 3. The relationship between permeability and formation factor is detailed by Bernard [1999]. The rock conductivities $\sigma_{r}$, at the fluid conductivities used for electrokinetic measurements (obtained directly or by extrapolation using the Revil and Glover model) are inferior to $1 \mathrm{mS} \mathrm{m}^{-1}$, except for the scoria MF201(3), where it reaches $1.3 \mathrm{mS} \mathrm{m}^{-1}$ (Table 2).

\subsection{Streaming Potential}

The streaming potential has been measured for 4-11 differential fluid pressure, 3 or 4 times for each sample. Figure 4 shows only the last set of measurements (the three last sets of measurements giving the same results, the first set corresponding to the transitory phase). We see that the streaming potential is proportional to the driving pore pressure, as expected from (1). This linearity has been verified previously for sand [Ahmad, 1964,

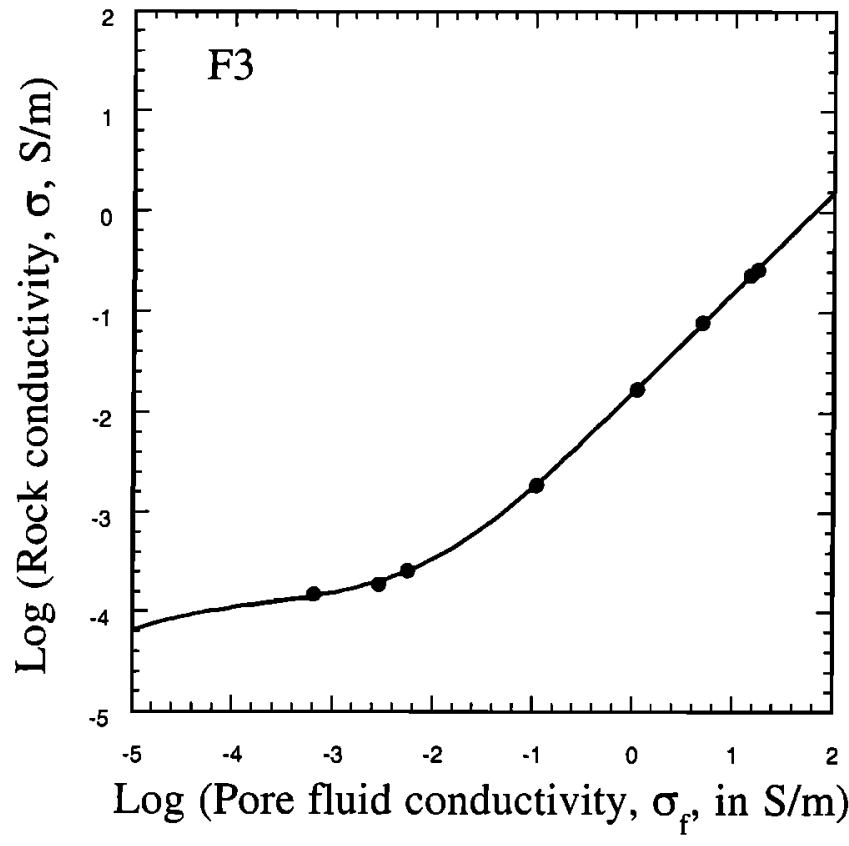

Figure 2. Rock electrical conductivity versus water conductivity, for sample F3.

Lorne et al., 1999a] and sandstone samples [Jounıaux and Pozzi, 1997].

For each sample, the coupling coefficient $C_{S}$ has been deduced from the mean (from the three or four sets of measurements) of the slopes of the straight lines streaming potential versus driving pore pressure, by linear fit to the data, using least squares regression. The values of these coupling coefficients (Table 3 ) range from -35 to $-4905 \mathrm{mV} \mathrm{MPa}{ }^{-1}$ for a $\mathrm{pH}$ and conductivity of the water, in equilibrium with the the rock, varying from 6.2 to 6.9 and 0.23 to $2 \mathrm{mS} \mathrm{m}^{-1}$, respectively.

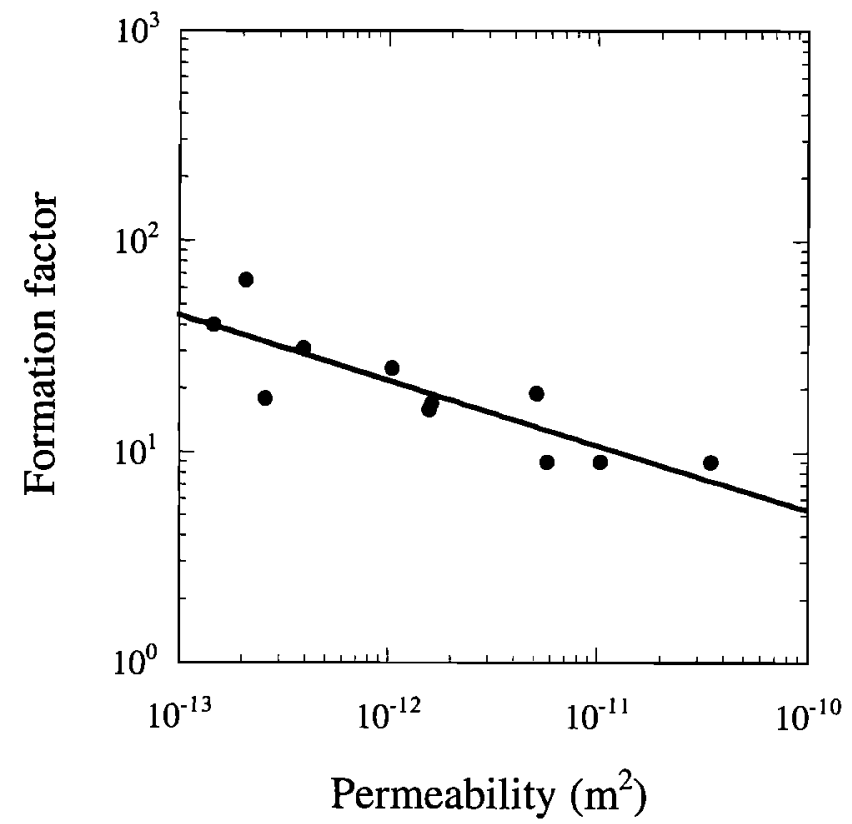

Figure 3. Formation factor versus permeability for all the studied samples. 


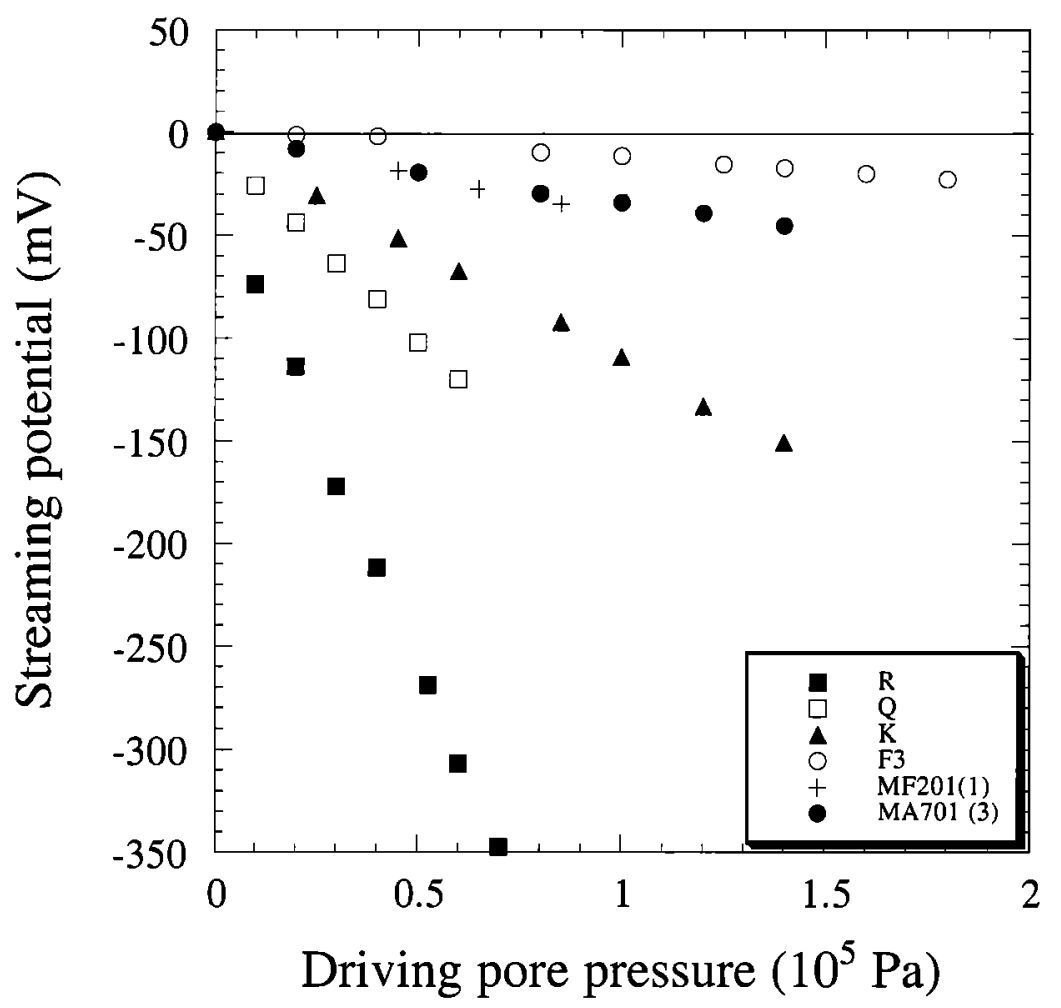

Figure 4. Measured streaming potential $\Delta V$ versus the applied pore pressure $\Delta \mathrm{P}$ for six samples.

Figure 5 displays the variation of the coupling coefficient with porosity, formation factor, and permeability. No specific correlation is observed with porosity or formation factor. However, the coupling coefficient increases, by more than 2 orders of magnitude, with increasing permeability. This reliance of the coupling coefficient with permeability may be a consequence of a dependency of the effective conductivity $\sigma_{\text {eff }}$ with permeability. Figure 6 exhibits this dependency. We observe a net decreasing of the effective conductivity, by more than 1 order of magnitude, with increasing permeability.

The dependency of the coupling coefficient on the permeability has been observed by Antraygues and $A u$ bert [1993] on quartz sands (1.5 to $12 \mathrm{~mm}$ grain size) when these authors measured the electric potential along a vertical column of porous material in which upward vapor and a downward liquid water (vapor condensation) flows occurred, and by Jouniaux and Pozzl [1995a] on Fontainebleau sandstone samples, with permeabilities ranging from $0.15 \times 10^{-15}$ to $1.2 \times 10^{-12} \mathrm{~m}^{2}$. Jouniaux and Pozzi [1995b] suggested that the decreasing coupling coefficient with the decreasing permeability of Fontainebleau sandstones could be induced by surface conductivity that may not be negligible, as first proposed for narrow cylindrical capillaries [Broz and Epstein, 1976]. In our samples, where the effective conductivity was measured instead of being inferred from surface conductance assumptions, we found a variation of the effective conductivity with permeability (Figure 6 ) of $\sim 1.3$ orders of magnitude. In order to be free of the dependence on the effective conductivity, the parameter $C^{\prime}$, which is independent from effective conductivity, has been calculated using (4). This parameter varies from -0.4 to $-8.5 \mathrm{mV}(\mathrm{MPa} \Omega \mathrm{m})^{-1}$ (Table 3 ). Figure 7 shows the $C^{\prime}$ parameter as a function of permeability. We observe that the electrokinetic coefficient still varies by a factor 20 in the studied samples, but no clear dependence with permeability is noted.

\subsection{The Zeta Potential}

The macroscopic zeta potential is deduced for each sample, using (1). The values obtained are given in Table 3 . The zeta potential ranges from -0.6 to -12.2 $\mathrm{mV}$. These values are relatively low. Four samples have zeta potential, in absolute value, lower than $2 \mathrm{mV}$, indicating that for these samples the $\mathrm{pH}$ of the distilled water in equilibrium with these rocks is close to the $\mathrm{pH}_{\mathrm{pzc}}$. (Value $\mathrm{pH}_{\mathrm{pzc}}$ represents the $\mathrm{pH}$ corresponding to the zero surface charge. At $\mathrm{pH}_{\mathrm{pzc}}$ the zeta potential is zero). Massenet and Van Ngoc [1985] measured the zeta potential in samples of volcanic ashes (from Mount Etna). The mineralogical composition of these ashes is relatively close to the composition of our samples. They obtained values of zeta potential ranging from -26 to $34 \mathrm{mV}$ for $\mathrm{pH}$ and fluid conductivity equivalent to these of our measurements. These values are superior to our values, but in the Mount Etna samples, $\mathrm{pH}_{\mathrm{pzc}}=4.4$. These differences can emanate from differences in mineralogical composition and particularly from a different percentage of glass in the groundmass.

The zeta potential varies from more than 1 order of 

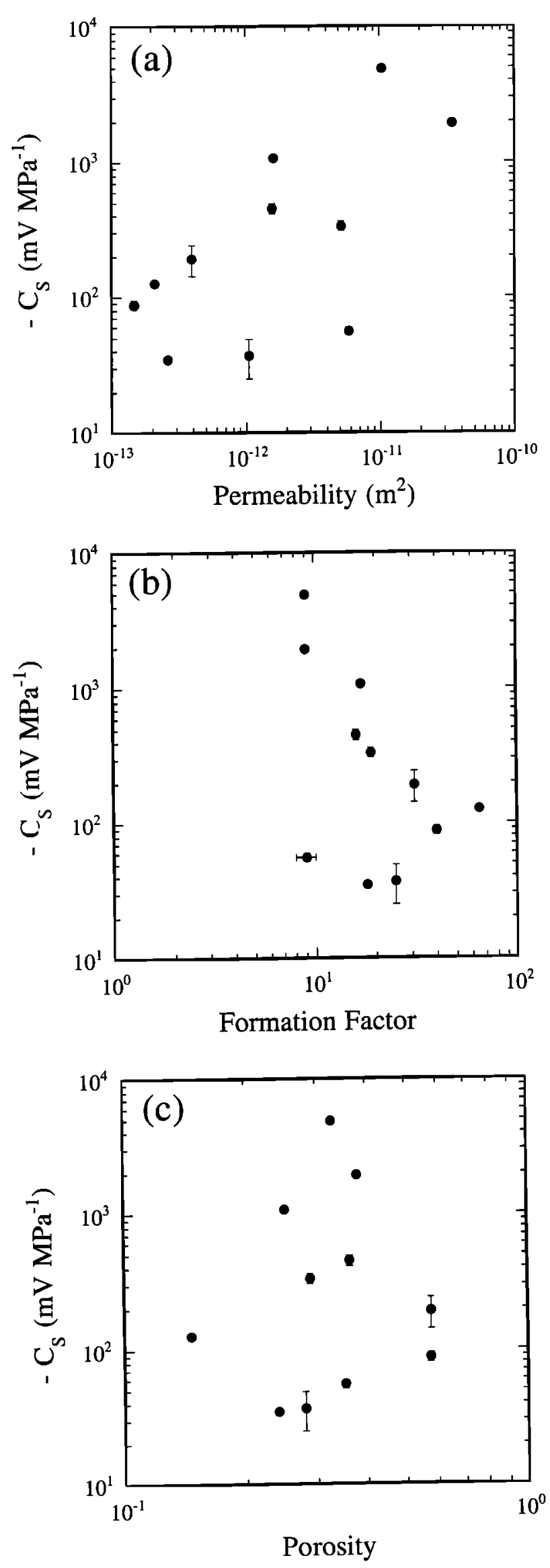

Figure 5. Measured coupling coefficient $C_{S}$ versus (a) permeability, (b) formation factor, and (c) porosity.

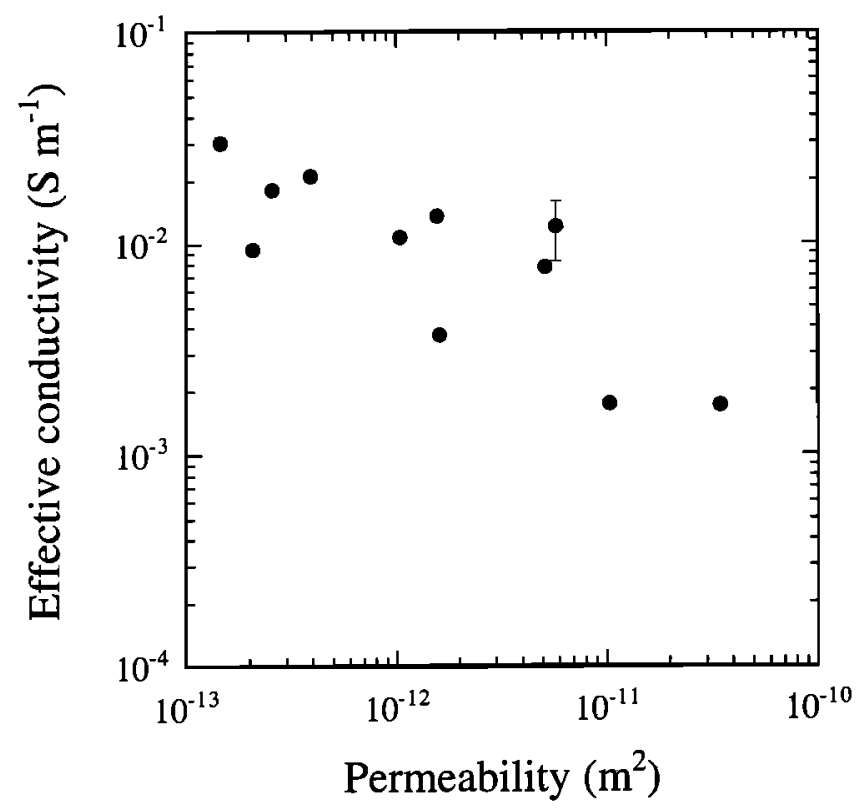

Figure 6. Measured effective conductivity $\sigma_{\text {eff }}$ as a function of permeability.

magnitude in the studied samples. This variation cannot be due to the effective conductivity, since we take $\sigma_{\text {eff }}$ into account to deduce the zeta potential. The effect of other parameters should be considered to explain this difference. The most influential parameters on the zeta potential are the mineralogical composition, the $\mathrm{pH}$, the fluid conductivity, and the temperature [ $L i$ and De Bruyn, 1966; Ishido and Mizutani, 1981; Revil et al., 1999a].

All the measurements were performed at the same temperature $\left(25^{\circ} \mathrm{C}\right)$. The $\mathrm{pH}$ of the deionized water, at the equilibrium with the samples, $\mathrm{pH}_{e}$, ranges from 6.2 to 6.9 (Table 3 ). It depends on the rock mineralogy. Thus, for the samples of the 1929 eruption, $\mathrm{pH}_{e}=6.2$, while for Paleo-Pelée stage samples, $\mathrm{pH}_{e}=6.6$. From the 1902 and P1 eruptions, which present a succession of the Plinian and Pelean mechanisms, in the samples emanating from the Pelean mechanism, $\mathrm{pH}_{e}=6.4$. The two samples coming from the Plinian mechanism have different values of $\mathrm{pH}_{e}(6.7$ and 6.9$)$, problably because the Plinian samples exhibit more heterogeneous groundmass composition than the Pelean samples do (P. Besson, personal communication, 1999). The $\mathrm{pH}_{e}$ of the Saint Vincent stage samples are all different. This stage is characterized by variations of composition that are relatively important.

Water conductivity in equilibrium with the rock depends on the mineralogical composition and on the equilibrium $\mathrm{pH}$ and varies from 0.2 to $2 \mathrm{mS} \mathrm{m}^{-1}$ (Table 3 ). In order to compare the $\zeta$ potential obtained on the different samples in the same physical conditions, we must calculate the values of this potential at the same values of $\mathrm{pH}$ and water conductivity (or water concentration).

In the case of quartz systems, at $\mathrm{pH}$ close to 7 and for solutions containing $\mathrm{K}^{+}$or $\mathrm{Na}^{+}$, the $\zeta$ potential may 
Table 3. Fluid and Effective Conductivities, $\mathrm{pH}$ of the water, Coupling Coefficient, Electrokinetic Coefficient, and Zeta Potential for Each Sample.

\begin{tabular}{|c|c|c|c|c|c|c|c|}
\hline Sample & $\sigma_{f}$ & $\sigma_{\text {eff }}$ & $p H_{e}$ & $C_{S}$ & $\mathrm{C}^{\prime}$ & $\zeta$ & $\zeta_{\text {cor }}$ \\
\hline $\mathrm{R}$ & 0.34 & 1.7 & 6.2 & $-4905+15$ & -8.5 & -12.2 & -19 \\
\hline Q & 0.23 & 1.7 & 6.2 & $-1940+30$ & -3.3 & -4.7 & -11 \\
\hline $\mathrm{K}$ & 0.23 & 3.7 & 6.4 & $-1078+4$ & -4.0 & -5.7 & -11 \\
\hline $\mathrm{MF} 201$ (1) & 1.31 & 13.6 & 6.8 & $-454+40$ & -6.2 & -8.8 & -11 \\
\hline MA701 (3) & 0.34 & 7.7 & 6.6 & $-335+28$ & -2.6 & -3.7 & -7 \\
\hline $\mathrm{J}$ & 0.74 & 21.0 & 6.7 & $-193+50$ & -4.1 & -5.8 & -9 \\
\hline F3 & 0.69 & 9.5 & 6.4 & $-127+5$ & -1.2 & -1.7 & -7 \\
\hline $\mathrm{M}$ & 2.00 & 30.3 & 6.9 & $-88+7$ & -2.7 & -3.8 & -5 \\
\hline MF201 (3) & 0.54 & 12.1 & 6.6 & $-56+4$ & -0.7 & -1.0 & -4 \\
\hline MA701 (1) & 0.78 & 18.1 & 6.6 & $-35+2$ & -0.6 & -0.9 & -4 \\
\hline MF201 (2) & 0.46 & 10.7 & 6.5 & $-37+12$ & -0.4 & -0.6 & -5 \\
\hline
\end{tabular}

Note that $\sigma_{f}$ indicates conductivity of fluid, in $\mathrm{mS} \mathrm{m}^{-1}, \sigma_{\text {eff }}$ indicates effective conductivity, in $\mathrm{mS} \mathrm{m}^{-1}, p H_{e}$ indicates the $\mathrm{pH}$ of the water at the equilibrium with the rock, $C_{S}$ indicates coupling coefficient, in $\mathrm{mV} \mathrm{MPa}^{-1}, C^{\prime}$ indicates electrokinetic coefficient, in millivolt $(\mathrm{MPa} \Omega \mathrm{m})^{-1}, \zeta$ indicates zeta potential from equation (1), and $\zeta_{\text {cor }}$ indicates zeta potential from equation (8), in $\mathrm{mV}$.

be analytically expressed as a function of temperature, $\mathrm{pH}$, and fluid concentration [Revil et al., 1999a] by

$$
\zeta=c-d \mathrm{pH}+b \log _{10} C_{f},
$$

where $C_{f}$ is the fluid concentration. The slopes $b$ and $d$ of (8) depend only on temperature. The zeta potential decreases in absolute value when the solution concentration increases. At $25^{\circ} \mathrm{C},(8)$ provides $b=-20 \mathrm{mV}$. This value is close to the one obtained by Pride and Morgan [1991], using a compilation of experimental data, who found $b=-26 \mathrm{mV}$. The parameter $c$ depends on temperature, on the total site density of the silica surface, and on the dissociation constant for

$$
>\mathrm{SiOH}^{0} \longrightarrow>\mathrm{SiO}^{-}+\mathrm{H}^{+}
$$

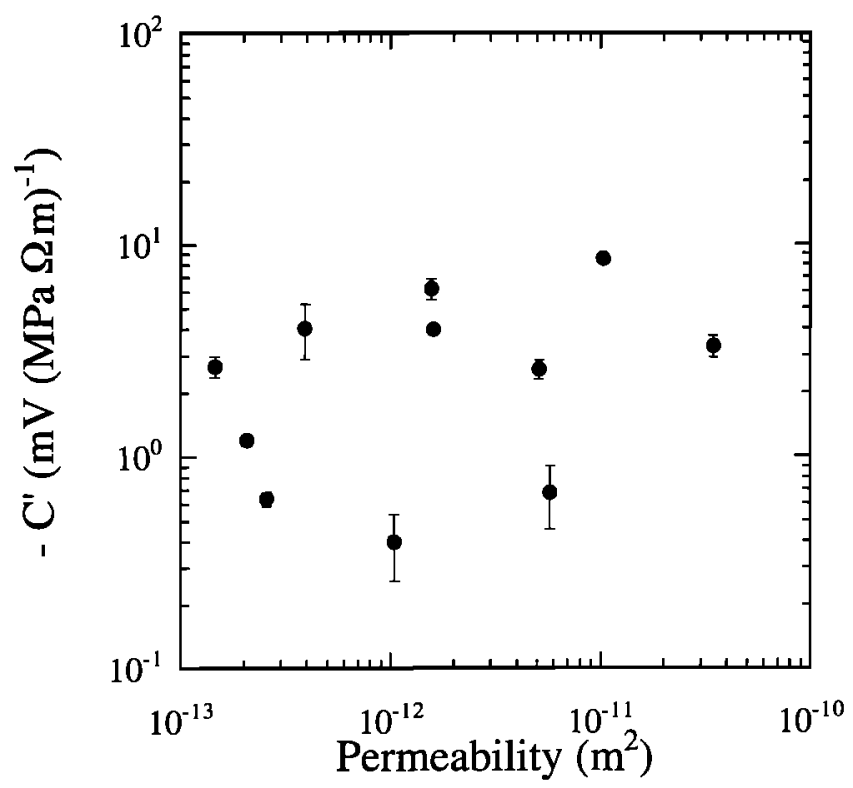

For volcanic rocks, having usually a complex mineralogical composition, the effect of $\mathrm{pH}$ and fluid conductivity on zeta potential cannot be explained analytically, using microscopic approach, as for quartz systems. The effect of these parameters may only be inferred empirically using experimental data. Unfortunately, few experimental works exist in the literature concerning the effect of these parameters on zeta potential. In particular, only two studies explored the effect of $\mathrm{pH}$ and fluid conductivity on zeta potential in rocks having mineralogical compositions similar to our samples: the Ishıdo and Mizutani [1981] work which examined the effect of $\mathrm{pH}$ in an andesitic sample and the Massenet and Van Ngoc [1985] work which studied the effect of $\mathrm{pH}$ and fluid concentration in samples of volcanic ashes (from Mount Etna). The mineralogical composition of these ashes is relatively close to the composition of our samples.

In order to calculate the values of the $\zeta$ potential of our samples, in the same physical conditions, we assumed that the variation of the zeta potential with water concentration and $\mathrm{pH}$ can be described by a relation similar to that of (8), as for quartz systems. We used the measurements of Massenet and Van Ngoc [1985] at $6 \leq \mathrm{pH} \leq 7$ and fluid concentration $\leq 10^{-3} \mathrm{~mol} \mathrm{~L}^{-1}$, to deduce the values of $b$ and $d$ parameters. We used these values $(b=0.4 \mathrm{mV}$ and $d=8 \mathrm{mV})$ to calculate zeta potential of our samples at $C_{f}=2.1 \times 10^{-5} \mathrm{~mol}$ $\mathrm{L}^{-1}$ and $\mathrm{pH}=7$. The values of zeta potential at $C_{f}=$ $2.1 \times 10^{-5} \mathrm{~mol} \mathrm{~L}^{-1}$ and $\mathrm{pH}=7$, after $\mathrm{pH}$ and fluid concentration corrections (equation (8)), are given in Table 3 . Figure 8 shows the zeta potential as a function of permeability before and after correction. We observe that after both corrections the dispersion of zeta potential is considerably reduced. The zeta potential ranges now from -4 to $-19 \mathrm{mV}$. The zeta potential reflects differences in mineralogical composition of the samples. It is therefore related to the different eruption mechanisms,

Figure 7. Computed parameter $C^{\prime}$ versus permeability. and we can observe that the lower values of zeta poten- 

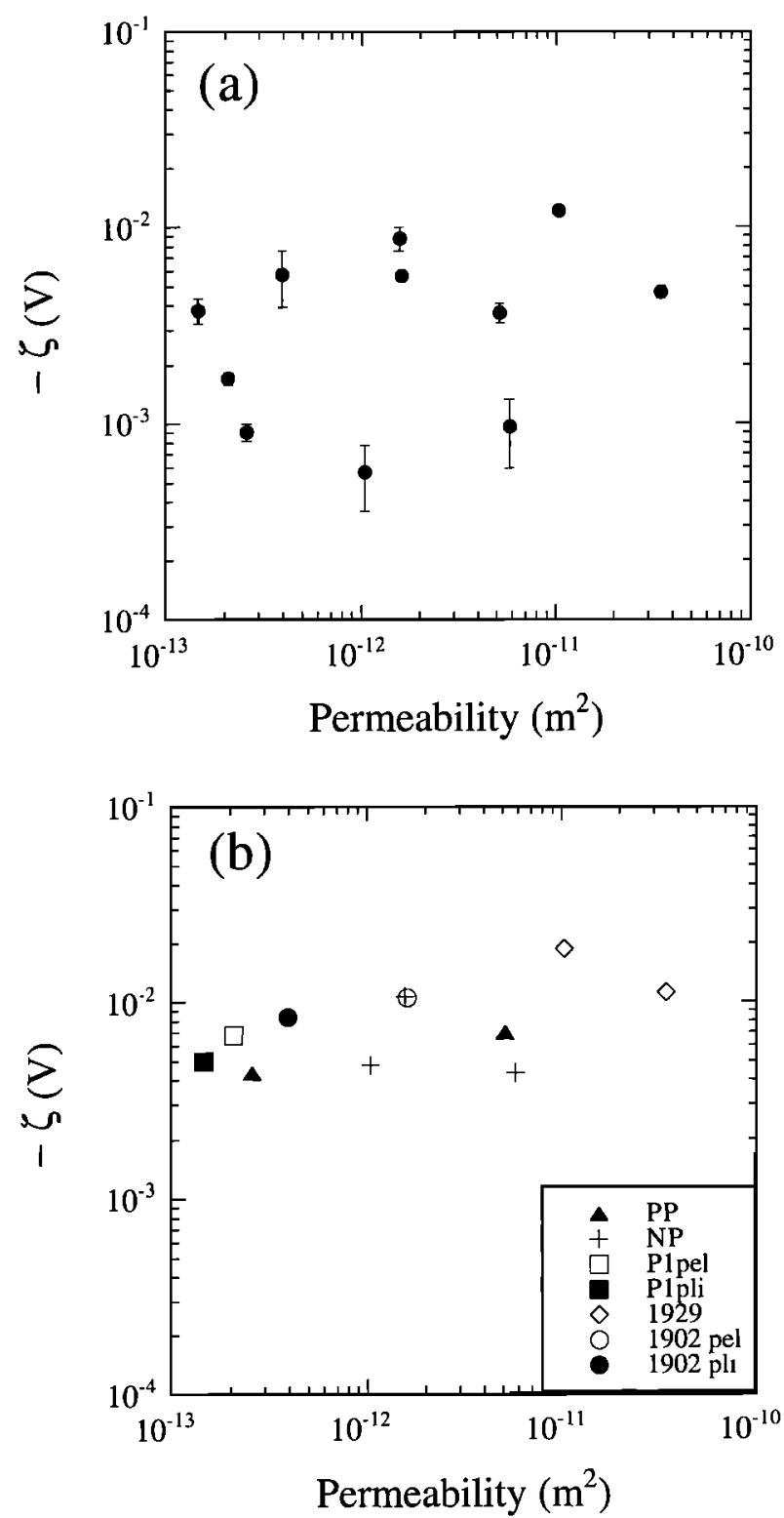

Figure 8. Zeta potential (a) deduced from equation (1) and (b) calculated from equation (8).

tial are obtained in the brecchias and scorias of Paléoand Néo-Pelée stages, while the higher values are observed in the 1929 eruption. For the P1 and 1902 eruptions, zeta potential is more important in samples from Peléan mechanism. These observations show that the zeta potential is very sensitive to the weak mineralogical composition variations.

\section{Streaming Potential on Volcanoes}

SP surveys on mountainous areas usually show a negative correlation between electrical potential and topographic elevation, implying that the higher the topographic elevation, the lower the potential. Such a correlation between $\mathrm{SP}$ and topographic elevation is the result of steady state fluid flow caused by spatial variations in the elevation of the water table [Ishıdo, 1989].
Indeed, the electrokinetic coupling coefficient is usually negative for rocks, and positive charges are induced to move along the fluid flow from the top to the bottom of the topographic slope. This SP anomaly reflects the piezometric surface, and the amplitude of the anomaly is related to the thickness of the nonsaturated zone [Aubert and Dana, 1994]. This topographic effect in a volcanic area can be $-1.6 \mathrm{mV} \mathrm{m}^{-1}$ [Hashımoto and Tanaka, 1995], $-1.9 \mathrm{mV} \mathrm{m}^{-1}$ [Lénat, 1987], $-3 \mathrm{mV} \mathrm{m} \mathrm{m}^{-1}$ [Aubert and Lıma, 1986], $-5 \mathrm{mV} \mathrm{m}{ }^{-1}$ [Aubert and Dana, 1994], or larger, $-10 \mathrm{mV} \mathrm{m}^{-1}$ [Ishıdo, 1989; Hashimoto and Tanaka, 1995]. In volcanic zones this topographic effect is modified by ascendant fluid flow, so that positive anomalies are usually observed, although it is not unusual to measure positive anomalies on extinct volcanoes too, induced by higher water-repellent levels. Large positive SP anomalies have been reported on La Fournaise volcano [Zlotnıckı et al., 1994], on Mount Somma-Vesuvius and Vulcano Island $\left[D_{\imath}\right.$ Maro et al., 1997], and on Unzen volcano [Hashimoto and Tanaka, 1995], and these anomalies are interpreted as the electric potentials generated by fluid flow in the hydrothermal ascendant circulations in the subsurface or greater depths. Recently, a huge anomaly of $4000 \mathrm{mV}$ in self potential was reported on Misti volcano (south Peru) [Finizola et al., 1998]. Since streaming potential is proportional to the pressure gradient (Figure 4), any source of fluid pressure gradient change will be an important factor for the electrokinetic process. Temporal monitoring of SP on volcanoes could reflect climatic variations [Morat et al., 1992], variations in hydrothermal circulations resulting from crack closure or opening, fluid pressure increases induced by stress changes, or thermal fluctuations [Malengreau et al., 1994].

Electrical resistivity of water sources and rivers on Mount Pelée has been measured to be $10-120 \Omega \mathrm{m}$, with $\mathrm{pH}=6.4$. Sources of hot water (up to $73^{\circ} \mathrm{C}$ ) showed also $\mathrm{pH}=6.4$. Moreover, resistivity of aquifers, measured via boreholes, was 20-72 $\Omega \mathrm{m}$ [Barat, 1984]. Considering an average water electrical resistivity of $50 \Omega \mathrm{m}$, one could expect a coupling coefficient of about -25 to $-406 \mathrm{mV} \mathrm{MPa}^{-1}$ in this volcano.

\section{Conclusion}

The measured coupling coefficient on 11 samples from Mount Pelée volcano has been found to vary with permeability. This variation has been explained by the effect of the effective conductivity, of the $\mathrm{pH}$, and of the fluid conductivity. The remaining variation of the zeta potential is due to the differences in mineralogy of the samples related to the eruption mechanisms.

This study demonstrates that it is important to perform electrokinetic measurements by controlling $\mathrm{pH}$ and ionic strength (or fluid conductivity) and by measuring the effective conductivity. A good understanding of the electrokinetic phenomenon on rock samples must involve joint measurements on intact samples and on crushed samples, in order to know the exact value of zeta potential in andesitic-water systems and its de- 
pendence on salinity and $\mathrm{pH}$. The electrokinetic process in unsatured medium and the effect of temperature have been theoretically quantified recently [Revil et al., 1999b]. The effects of vapor, and other gases, specially $\mathrm{CO}_{2}$, on electrokinetics in volcanic samples, must be quantified in order to better understand the $\mathrm{SP}$ anomalies observed on volcanoes. Indeed, very recent measurements show that injected gases in soil, with various effects on $\mathrm{pH}$, induced different $\mathrm{SP}$ responses [Martinelli, 1998].

Acknowledgments. This research is a collaboration with C. Philippe, ENSAM Laboratoire de Mécanique des Structures, Paris. We thank S. Jacquet and D. Corneille from ENSAM Paris and G. Marolleau from ENS Paris for the construction of the apparatus. The authors acknowledge fruitful exchanges with A. Revil, P. Besson and G. Boudon. The reviews of the manuscript by M. Aubert, P. Glover, and the Associate Editor greatly improved this paper. This research was supported by CNRS. This is a CNRS-INSUPNRN contribution no. 215 (Thème risques volcaniques), a CNRS-INSU-PNRH contribution no. 216 (Thème circulation des fluides dans la croûte) and a EEC contribution of the Environmental and Climate Work programme (Volcanic risk). IPG contribution no. 1655.

\section{References}

Adamson, A.W., Physical Chemistry of Surfaces, WileyInterscience, New-York, 1976.

Ahmad, M., A laboratory study of streaming potentials, Geophys. Prospect., 12, 49-64, 1964.

Anderson, L. A., and G. R. Johnson, Application of the self-potential method to geothermal exploration in Long Valley, California, J. Geophys. Res., 81, 1527-1532, 1976.

Antraygues, P., and M. Aubert, Self potential generated by two-phase flow in a porous medium: Experimental study and volcanological applications, J. Geophys. Res., 98, 22,273-22,281, 1993.

Aubert, M., and J. C. Baubron, Identification of a hidden thermal fissure in a volcanic terrain using a combination of hydrothermal convection indicators and soil-atmosphere analysis, J. Volcanol. Geotherm. Res., 35, 217-225, 1988.

Aubert, M., and I. Dana, Interpretation of the self potential radial profiles in volcanology: Possibilities of the SP method for the monitoring of the active volcanoes, Bull. Soc. Geol. Fr., 2, 113-122, 1994.

Aubert, M., and G. Kieffer, Evolution d'une intrusion magmatique dans le flanc sud de l'Etna entre juin 1982 et juin 1983: Résultats de potentiel spontané (PS) et essai d'interprétation de l'éruption de $1983, C$. R. Acad. Sci., Ser. II, 298, 379-382, 1984.

Aubert, M., and E. Lima, Hydrothermal activity detected by self-potential measurements at the N-S volcanic axis between the volcanoes Nevado de Colima and Volcan de Fuego de Colima, Geofis. Int., 25, 575-586, 1986.

Aubert, M., R. Auby, F. Bourlet, and Y. Bourlet, Contribution à la surveillance de l'áctivité de l'Etna à partir de l'étude des zones fumerolliennes, Bull. Volcanol., 47 , 1039-1050, 1984.

Barat, A., Etude du role des eaux souterraines dans le mécanisme des éruptions phréatiques: Application à la Montagne Pelée de Martinique et à la Soufriére de Guadeloupe, Ph.D thesis, Univ. de Bordeaux, France, 1984.

Bernabé, Y., Streaming potential in heterogeneous networks, J. Geophys. Res., 103, 20,827-20,841, 1998.

Bernard, M. L., Etude expérimentale des propriétés physiques des roches pyroclastiques de la montagne Pelée, Ph.D thesis, Univ, Paris 7, Paris, 1999.

Bourbié, T., and B. Zinszner, Hydraulic and acoustic properties as a function of porosity in Fontainbleau sandstone, J. Geophys. Res., 90, 11,524-11,532, 1985.

Broz, Z., and N. Epstein, electrokinetic flow through porous media composed of fine cylindrical capillaries, J. Colloid Interface Sci., 56, 605-612, 1976.

Coelho, D., M. Shapiro, J. F. Thovert, and P. M. Adler, Electroosmotic phenomena in porous media, J. Colloid Interface Sci., 181, 169-190, 1996.

Corwin, R. F., and D. B. Hoover, The self-potential method in geothermal exploration, Geophysics, 44, 226-245, 1979.

Di Maio, R., P. Mauriello, D. Patella, Z. Petrillo, S. Piscitelli, A. Siniscalchi, and M. Veneruso, Self-potential, geoelectric and magnetotelluric studies in Italian active volcanic areas, Ann. Geofis., XL-2, 519-537, 1997.

Fenoglio, M.A., M. J. S Johnston, and J. D. Byerlee, Magnetic and electric fields associated with changes in high pore pressure in fault zones: Application to the Loma Prieta ULF emissions, J. Geophys. Res., 100, 12,951-12,958, 1995.

Fichaut, M., R. C. Maury, H. Traineau, D. Westercamp, J. L. Joron, A. Gourgaud, and C. Coulon, Magmatology of Mount Pelée (Martinique F.W.I.), III, Fractional crystallization versus magma mixing, J. Volcanol. Geotherm. Res., 38, 189-212, 1989.

Finizola, A., D. Ramos, and O. Macedo, Self-potential studies of hydrothermal systems structure on Misti and Ubinas volcanoes, South Peru, paper presented at the XXIII General Assembly, Eur. Geophy. Soc., Nice, C194, 1998.

Fitterman, D. V., Theory of electrokinetic-magnetic anomalies in a faulted half-space, J. Geophys. Res., 84, 60316040, 1979. (Correction, J. Geophys. Res., 86, 9585-9588, 1981.)

Fujinawa, Y., T. Kumagai, and K. Takahashi, A study of anomalous underground electric field variations associated with a volcanic eruption, Geophys. Res. Lett., 19, 9-12, 1992.

Hashimoto, T. and Y. Tanaka, A large self-potential anomaly on Unzen volcano, Shimabara peninsula, Kyushu Island, Japan, Geophys. Res. Lett., 22, 191-194, 1995.

Hunter, R. J., Zeta Potential in Colloid Science, Academic, London, 1981.

Ishido, T., Self-potential generation by subsurface water flow through electrokinetic coupling, in Detection of Subsurface Flow Phenomena, Lecture Notes Earth Sci., Vol. 27, p. 121-131, Springer-Verlag, New York, 1989.

Ishido, T., and H. Mizutani, Experimental and theoretical basis of electrokinetic phenomena in rock-water systems and its applications to geophysics, J. Geophys. Res., 86, 1763-1775, 1981.

Jouniaux, L., and J.-P. Pozzi, Streaming potential and permeability of saturated sandstones under triaxial stress: Consequences for electrotelluric anomalies prior to earthquakes, J. Geophys. Res., 100, 10,197-10,209, 1995a.

Jouniaux, L., and J.-P. Pozzi, Permeability dependence of streaming potential in rocks for various fluid conductivities, Geophys. Res. Lett., 22, 485-488, 1995 b.

Jouniaux, L., and J.-P. Pozzi, Laboratory measurements anomalous 0.1-0.5 Hz streaming potential under geochemical changes: Implications for electrotelluric precursors to earthquakes, J. Geophys. Res., 102, 15,335-15,343, 1997.

Jouniaux, L., S. Lallemant, and J.-P. Pozzi, Changes in the permeability, streaming potential and resistivity of a claystone from the Nankai prism under stress, Geophys. Res. Lett., 21, 149-152, 1994.

Kan, R., and P. N. Sen, Electrolytic conduction in peri- 
odic arrays of insulators with charges, J. Chem. Phys., $86,5748-5756,1987$.

Lénat, J.-F., Structure et dynamique internes d'un volcan basaltique intraplaque océanique: Le Piton de La Fournaise (Ile de la Réunion), $\mathrm{Ph}$. D thesis, Clermont-Ferrand II, France, 1987.

Li, H. C., and P. L. De Bruyn, electrokinetic and adsorption studies on quartz, Sur. Sci., 5, 203-220, 1966.

Lorne, B., F. Perrier, and J. P. Avouac, Streaming potential measurements, 1, Properties of the electrical double layer from crushed rock samples, J. Geophys. Res., 104, 17,857$17,877,1999$ a.

Lorne, B., F. Perrier, and J. P. Avouac, Streaming potential measurements, 2, Relationship between electrical and hydraulic flow patterns from rock samples during deformation, J. Geophys. Res., 104, 17,879-17,896, 1999b.

Malengreau, B., J. F. Lénat, and A. Bonneville, Cartography and temporal observation of self-potential (SP) anomalies at Piton de la Fournaise, Bull. Soc. Géol. Fr., 165, 221-232, 1994.

Martinelli, G., The possible joint appearance of pre-seismic geochemical and geoelectrical anomalies in tectonically active areas, paper presented at the XXIII General Assembly, Eur. Geophy. Soc., Nice, C171, 1998.

Massenet, F., Etude du phénomene de polarisation spontanée sur les volcans actifs et applications à la prospection et à la surveillance sur lEtna (Sicile), Ph. D thesis, Inst. Nat. Polytech. de Lorraine, Nancy, France, 1983.

Massenet, F., and P. Van Ngoc, Experimental and theoretical basis of self-potential phenomena in volcanic areas with reference to results obtained on mount Etna, Earth Planet. Sci. Lett., 73, 415-429, 1985.

Michel, S, and J. Zlotnicki, Self-potential and magnetic surveying of La Fournaise volcano (Réunion Island): Correlations with faulting, fluid circulation, and eruption, $J$. Geophys. Res., 103, 17,845-17,857, 1998.

Mizutani, H., T. Ishido, T. Yokokura, and S. Ohnishi, Electrokinetic phenomena associated with earthquakes, Geophys. Res. Lett., 3, 365-368, 1976.

Morat, P., J.-L. Le Mouël, G. Nover, and G. Will, Annual variation of the water saturation of a highly porous rock driven by a seasonal temperature variation and measured by an array of electrodes, C. R. Acad. Sci., Ser. II, 315, 1083-1090, 1992.

Nourbehecht, B., Irreversible thermodynamic effects in inhomogeneous media and their applications in certain geoelectric problems, Ph. D thesis, Mass. Inst. of Technol., Cambridge, Mass., 1963.

Overbeek, J. T. G., Electrochemistry of the double layer, in Colloid Science, vol. 1, Irreversible Systems, edited by H. R. Kruyt, pp. 115-193, Elsevier Sci., New York, 1952.

Perrier, F., M. Trique, B. Lorne, J. P. Avouac, S. Hautot, and $P$. Tarits, Electrical variations associated with yearly lake level variations, Geophys. Res. Lett., 25, 1955-1958, 1998.

Perrier, F., M. Trique, J. Aupiais, U. Gautam, and P. Shrestha, Electric potential variations associated with periodic spring discharge in western Nepal, C. R. Acad. Sci. Paris, Ser. II, 328, 73-79, 1999.

Pozzi, J.-P., and L. Jouniaux, Electric effects of fluid circulation in sediments and seismic prediction, C.R. Acad. Sci., Ser. II, 328, 73-77, 1994.

Pozzi, J. P., J. L. Le Mouël, J. C. Rossignol, and J. Zlotnicki, Magnetic observations made on La Soufrière volcano (Guadeloupe) during the 1976-1977 crisis, J. Volcanol. Geotherm. Res., 5, 217-237, 1979.
Pride, S. R., Governing equations for the coupled electromagnetics and acoustics of porous media, Phys. Rev. B, Condens. Matter., 50, 15,678-15,696, 1994.

Pride, S. R., and F. D. Morgan, electrokinetic dissipation induced by seismic waves, Geophysics, 56, 914-925, 1991.

Revil, A., and P. W. J. Glover, Theory of ionic-surface conduction in porous media, Phys. Rev. B, Condens. Matter., $55,1757-1773,1997$.

Revil, A., and P. W. J. Glover, Nature of surface electrical conductivity in natural sands, sanstones, and clays, Geophys. Res. Lett., 25, 691-694, 1998.

Revil, A., and P. A. Pezard, Streaming electrical potential anomaly along faults in geothermal areas, Geophys. Res. Lett., 25, 3197-3200, 1998.

Revil, A., P. A. Pezard, and P. W. J. Glover, Streaming potential in porous media, 1 , Theory of the zeta potential, J. Geophys. Res., 104, 20,021-20,031, 1999a.

Revil, A., H. Schwaeger, L. M. Cathles III, and P. D. Manhardt, Streaming potential in porous media, 2, Theory and application to geothermal systems, J. Geophys. Res., 104, 20,033-20,048, 1999b.

Sill, W. R., Self-potential modeling from primary flows, Geophysics, 48, 76-86, 1983.

Somasundaran, P., and R. D. Kulkarni, A new streaming potential apparatus and study of temperature effects using it, J. Colloid Interface Sci., 45, 591-600, 1973.

Trique, M., P. Richon, F. Perrier, J. P. Avouac, and J. C. Sabroux, Radon emanation and electric potential variations associated with transient deformation near reservoir lakes, Nature, 399, 137-141, 1999.

Vincent, P. M., J. L. Bourdié, and G. Boudon, The primitive volcano of Mount Pelée: Its construction and partial destruction by flank collapse, J. Volcanol. Geotherm. Res., 38, 1-15, 1989.

Westercamp, D., Petrology of the volcanic rocks of Martinique, West Indies, Bull. of Volcanol., 39, 175-200, 1976.

Zlotnicki, J., and J. L. Le Mouël, Possible electrokinetic origin of large magnetic variations at La Fournaise volcano, Nature, 343, 633-635, 1990.

Zlotnicki, J., S. Michel, and C. Annen, Self-potential anomalies and convective systems on $\mathrm{La}$ Fournaise volcano (Réunion Island, France), C. R. Acad. Sci., Ser. II, 318 , 1325-1331, 1994.

Zlotnicki, J., G. Boudon, J. P. Viodé, J.- F. Delorne, and A. Mille, Hydrothermal circulation beneath Mount Pelée inferred by Self-potential surveying. Structural and tectonic implications, J. Volcanol. Geotherm. Res., 84, 7391, 1998.

Zohdy, A. A. R., L. A. Anderson, and L. J. P. Muffler, Resistivity, self potential and induced polarization surveys of a vapor-dominated geothermal system, Geophysics, 38, 1130-1144, 1973.

Laurence Jouniaux, Jean Pierre Pozzi, Laboratoire de Géologie, Ecole Normale Supérieure de Paris, 24, rue Lhomond, F-75231, Paris cedex, France. Email: jouniaux@geologie.ens.fr

Marie Lise Bernard, Maria Zamora Laboratoire des Géomatériaux, Institut de Physique du Globe de Paris, 4 Place Jussieu, F-75252 Paris Cedex 05, France.

(Received December 9, 1998; revised November 30, 1999; accepted December 8, 1999.) 